\title{
The Influence of Various Matrixes on the Strength Properties of Moulding Sands with Thermally Hardened Hydrated Sodium Silicate for the Ablation Casting Process
}

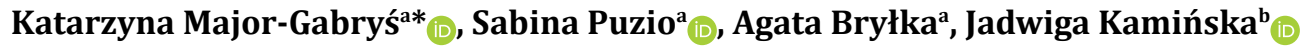 \\ ${ }^{\mathrm{a} A G H}$ University of Science and Technology, Faculty of Foundry Engineering, Department of Moulding Materials, \\ Mould Technology and Foundry of Non-ferrous Metals, Mickiewicza 30, 30-059 Krakow, Poland \\ ${ }^{\mathrm{b}}$ Lukasiewicz Research Network - Krakow Institute of Technology, Zakopianska 73, 30-418 Krakow, Poland \\ *e-mail: katmg@agh.edu.pl
}

(C) 2021 Authors. This is an open access publication, which can be used, distributed and reproduced in any medium according to the Creative Commons CC-BY 4.0 License requiring that the original work has been properly cited.

Receive 5 May 2021/Accepted: 23 June 2021/ Published online: 5 July 2021

This article is published with open access at AGH University of Science and Technology Press

\begin{abstract}
The essence of ablation casting technology consists in pouring castings into single-use moulds made from the mixture of sand and a water-soluble binder. After pouring the mould with liquid metal yet while the casting is still solidifying, the mould destruction (washing out, erosion) takes place using a stream of cooling medium, which in this case is water. This paper focuses on the selection of moulding sands with hydrated sodium silicate for moulds used in ablation casting. The research is based on the use of water glass 145 and 150 as binders. As part of the research, loose moulding mixtures based on two silica sands from different sand mines with different content of binders were prepared. The review of literature data and the results of own studies have shown that moulding sand with hydrated sodium silicate hardened by dehydration is characterized by sufficient strength properties to be used in the ablation casting process. Our own research also confirmed the possibility of using these sand mixtures in terms of both casting surface quality and sand reclamation. The results presented in this paper prove that both sand grains and types of binder tested may be used as components in moulding sands devoted to ablation casting.
\end{abstract}

\section{Keywords:}

innovative foundry technologies and materials, moulding sand, ablation casting, water glass, thermal curing

\section{INTRODUCTION}

Ablation casting is a term taken probably from the Latin ablatio meaning removal or ablutio which means washing. The essence of ablation casting technology consists in pouring castings in single-use moulds made from a mixture of sand and a water-soluble binder. After pouring the mould with liquid metal, while the casting is still solidifying, it is destroyed (washed out, erased). It takes place using a stream of cooling medium, which in this case is water. China is considered to be the precursor of ablation casting technology [1] A piece of rope or cord was coated with clay which was fired and washed out, and a mould obtained in this way was filled with liquid metal. This technique was used to produce dish handles from around $1600 \mathrm{BC}$ (Fig. 1).
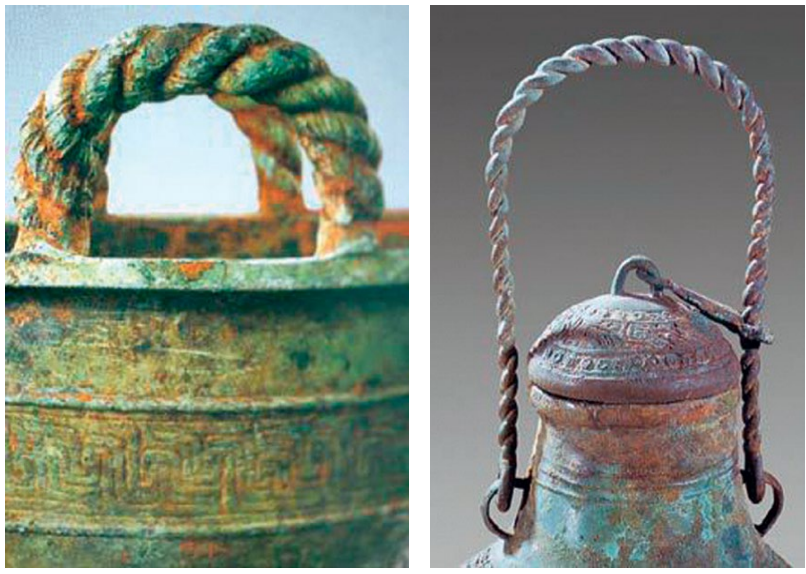

Fig. 1. Examples of the use of ablation in ancient China [1] 
In 2006, Alotech patented a casting station using the ablation casting method. The process of ablation casting consists of the following steps (1) make a mould of aggregates bonded with a water-soluble binder such as sodium silicate, (2) fill the mould cavity with a molten metal, (3) wait for a required delay between the mould filling and the start of ablation, and (4) start ablation of the mould [2]. Figure 2 shows an example of the ablation casting process proposed by Alotech [3]. The molten metal poured into the cavity of the sand moulds which are located on a belt conveyor and are moved horizontally to the water jets, is firstly cooled in the sand mould. As the mould travels toward the water jets, mould ablation starts from the edge of the mould, reaches the distal end of the solidifying casting, and moves progressively toward the feeder of the casting shown in Figure 2a, until the casting is solidified (Fig. 2b). The sand mould is broken down under high water pressure [2-8].

a)

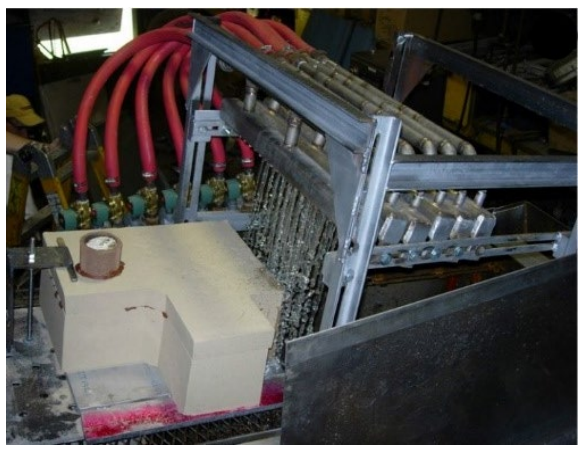

b)

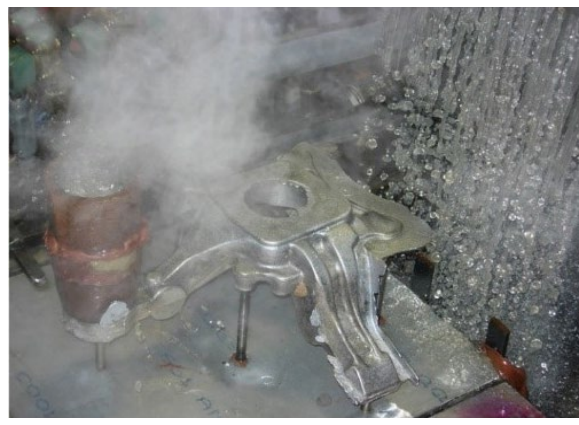

Fig. 2. View of the ablation casting process of a steering knuckle proposed by Alotech (a) with a solidified casting (b) [7]

Ablation casting technology offers advantages such as:

- The mould is destroyed with a stream of liquid medium during the casting solidification process, which eliminates the additional operation of knocking out from the mould and considerably reduces the dust pollution in a foundry plant.

- Some components of the moulding sand can be reclaimed.

- There is no air gap between the mould and the top layer of the cooled casting, which limits the heat flow to the outside. This enables solidification under the conditions of unprecedentedly large temperature gradients and high solidification rates. The mechanical properties of castings made using the ablation casting technology are reported to be superior to that made using low-pressure permanent mould (LPPM) casting process $[2,8]$.
- Controlled, directional cooling, achieved in this technology, favours the elimination of shrinkage porosity.

- The economic factor of the process is making high-quality castings in compact, single-use moulds as compared to high-tech permanent-mould technologies.

- The ecological factor associated with the use of an inorganic water-soluble binder.

The effect of ablation casting on solidification characteristics, microstructure formation, and mechanical properties of the casts have also been described in several publications $[2,9-12]$.

\section{RESEARCH}

The moulding sand used in the modified ablation casting process should be characterized by a durability that allows the transfer of the hydrostatic pressure of the liquid metal while being susceptible to the destructive effect of the cooling medium [13]. The use of hydrated sodium silicate as a binder for ablation casting technology is therefore justified. The inorganic binder is water-soluble and environmentally friendly. The ecological nature of the binder currently makes it the object of numerous studies [14], while modern processes using hydrated sodium silicate are increasingly used in foundry practice.

Figure 3 shows the modified ablation casting process steps elaborated in the Lukasiewicz Research Network Krakow Institute of Technology. A patent application for the technology has been filed [15] In previous studies, the authors proposed the use of moulding sands with a Cordis binder [16] produced by the Hüttenes-Albertus Company. It was a new-generation inorganic binder based on hydrated sodium silicate. Its hardening occurred under the effect of high temperature. In that technology, a loose inorganic Anorgit additive [16] was also used as an agent which prevents burn-on defects and improves the durability of cores, mitigating the adverse effect of humidity present in the environment [16].
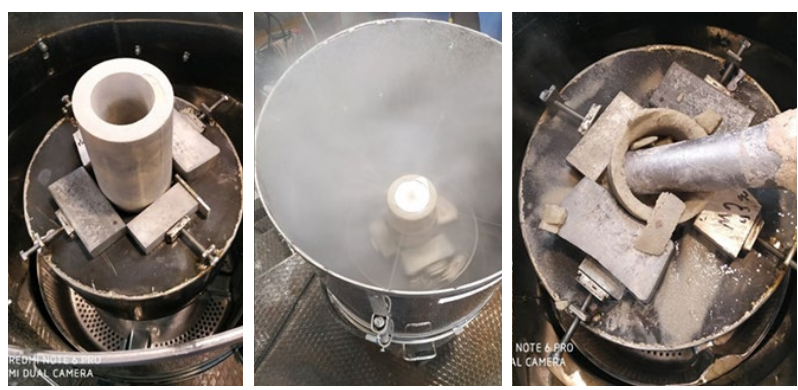

Fig. 3. Modified ablation casting process steps; Lukasiewicz Research Network - Krakow Institute of Technology [17]

Previous works [17] included preliminary semi-industrial tests were carried out on the use of moulding sand with water glass 145 in the manufacture of moulds for ablation casting. The potential to use these sand mixtures has been confirmed in terms of both casting surface quality and sand reclamation. 


\section{EXPERIMENTAL PROCEDURE}

As part of our own research, we proposed using moulding sands with hydrated sodium silicate thermally cured by dehydration as a material for the moulds in ablation casting. The main advantage of the dehydration process is the achievement of high strength properties, much higher than in the case of chemical hardening, combined with the absence of harmful products of the chemical reaction of hardening.

The mechanism of thermal curing of hydrated sodium silicate consists in its dehydration. It has been found that in the temperature range from $20^{\circ} \mathrm{C}$ to about $70^{\circ} \mathrm{C}$, free water is removed, while in the temperature range from about $115^{\circ} \mathrm{C}$ to about $140^{\circ} \mathrm{C}$, the removal of bound water occurs [18-20].

As a result of the thermal curing of sodium water glass, a structure composed of precipitated, amorphous, monolithic silicate shells is formed. The inverted reactions produce a gel (physical hardening) [18].

The aim of this paper was the comparison of the influence of different sand matrixes and different binder types on the strength properties of moulding sands. Moulding sands based on following sand matrixes were used:

- $1 \mathrm{~K}$ silica sand from the Grudzen Las Company with a main fraction of 0.20/0.40/0.315,

- silica sand from the Sibelco Poland Company; classified according to the Polish standard PN-85/H-11001 as medium; with the value of the main fraction of $84 \%$, which determines the sand as homogeneous.

As a binder, the inorganic water glass 145 and water glass 150 were used in an amount of 1.0, 1.5 and 2.0 parts by weight. Chosen properties of binders are shown in Table 1.

Table 1

Chosen properties of water glass 145 and water glass 150 [21, 22]

\begin{tabular}{ccc}
\hline Property / unit & $\begin{array}{c}\text { Water glass 145 } \\
\text { binder }\end{array}$ & $\begin{array}{c}\text { Water glass 150 } \\
\text { binder }\end{array}$ \\
\hline form & water solution & water solution \\
\hline physical condition & liquid & liquid \\
\hline colour & colourless & colourless \\
\hline smell & odourless & odourless \\
\hline $\mathrm{Na}_{2} \mathrm{O}+\mathrm{SiO}_{2}$ (min), $\%$ & 39 & 40 \\
\hline $\begin{array}{c}\mathrm{Na}_{2} \mathrm{O} / \mathrm{SiO}_{2} \\
(\text { molar module) }\end{array}$ & $2.4-2.6$ & $1.9-2.1$ \\
\hline $\begin{array}{c}\text { density } \\
\left.\text { (in temp. } 20^{\circ} \mathrm{C}\right), \mathrm{g} / \mathrm{cm}^{3}\end{array}$ & $1.45-1.48$ & $1.50-1.53$ \\
\hline $\begin{array}{c}\text { viscosity } \\
\left.\text { (in temp. } 20^{\circ} \mathrm{C}\right)\end{array}$ & 1 & 1 \\
\hline
\end{tabular}

Moulding sands were prepared in a laboratory ribbon mixer, type LMR-2. The sand was mixed with the additive for 60 seconds, then the binder was introduced and the whole was mixed for another 150 seconds.

From the moulding sands, standard specimens were prepared for bending strength tests. Specimens were made in a universal LUT shooter. They were cured at $160^{\circ} \mathrm{C}$ for 30 , 60,90 and 120 seconds. The time and pressure of shooting were the same for all the specimens and amounted to 2 seconds and 0.5 $\mathrm{MPa}$, respectively.

Measurements of the moulding sand bending strength were carried out on an LRu-2 type apparatus in accordance with guidelines given in the $\mathrm{PN}-83 / \mathrm{H}-11073$ standard.

The moulding sands' properties were tested in both a hot state (directly after the removal from shooting machine) and a cold state (after 1 hour of curing at ambient temperature).

\section{RESULTS AND DISCUSSION}

Figures 4-7 show the obtained results of bending strength tests of moulding sands with water glass.

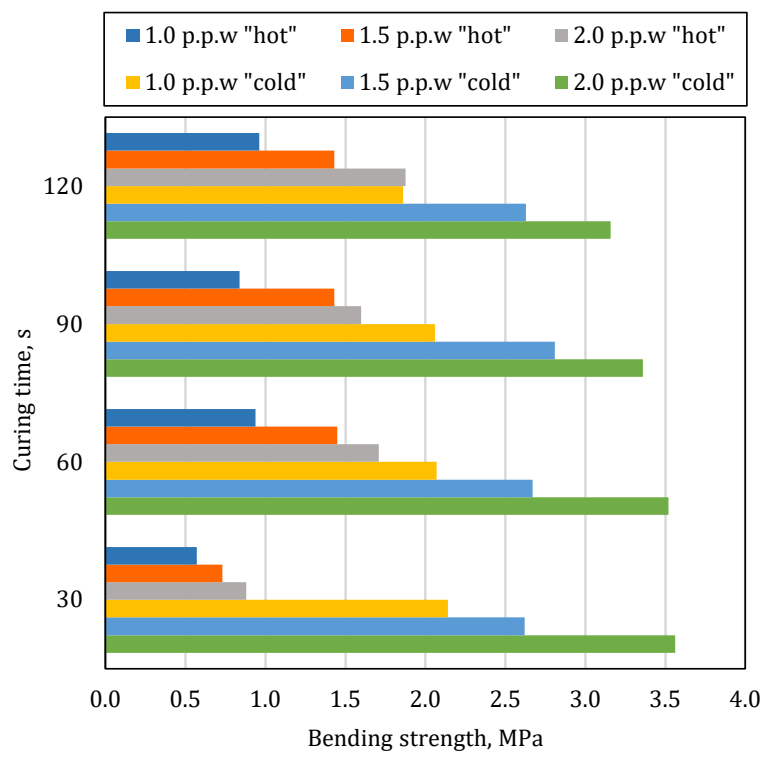

Fig. 4. The influence of R145 binder amount on bending strength properties of moulding sand based on Grudzen Las sand matrix and hardened in $160^{\circ} \mathrm{C}$ [23]

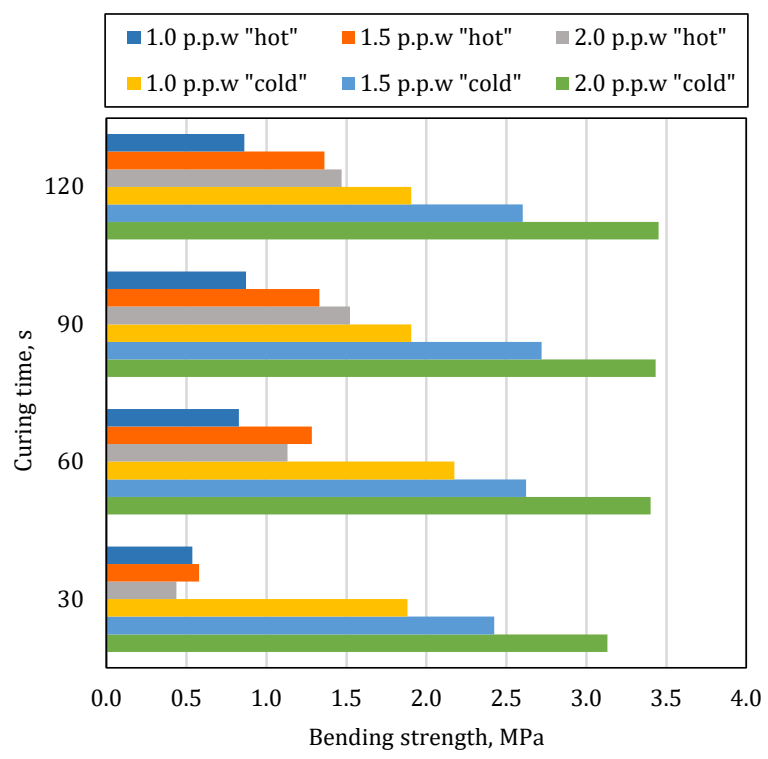

Fig. 5. The influence of R150 binder amount on bending strength properties of moulding sand based on Grudzen Las sand matrix and hardened in $160^{\circ} \mathrm{C}[23]$ 


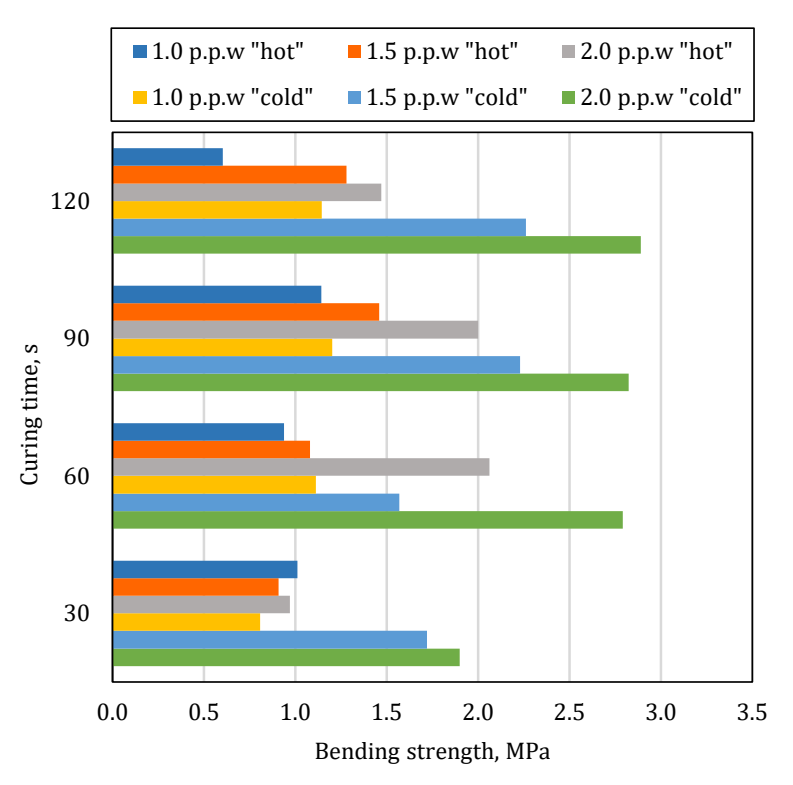

Fig. 6. The influence of R145 binder amount on bending strength properties of moulding sand based on Sibelco sand matrix and hardened in $160^{\circ} \mathrm{C}$ [23]

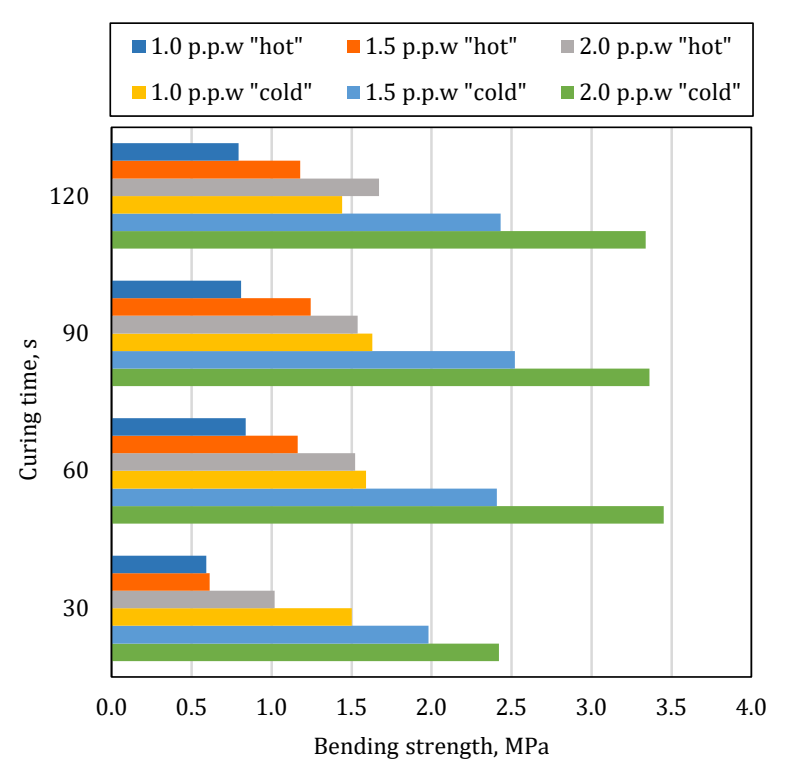

Fig. 7. The influence of R150 binder amount on bending strength properties of moulding sand based on Sibelco sand matrix and hardened in $160^{\circ} \mathrm{C}$ [23]

In the case of the use of the Grudzen Las sand matrix to prepare moulding sands with hydrated sodium silicate, the obtained test results for two types of binder, R145 and R150, were similar. Moulding sands with a content of 1.0 p.p.w. tested "hot" are characterized by strength of approx. $0.55 \mathrm{MPa}$ when hardened for $30 \mathrm{~s}$ and approx. $0.90 \mathrm{MPa}$ when hardened for $120 \mathrm{~s}$. Moulding sands with a content of 1.5 p.p.w. tested "hot" have a strength of approx. 0.7 MPa when hardened for $30 \mathrm{~s}$ and approx. 1.4 MPa when hardened for 120 s. Moulding sands with a content of 2.0 p.p.w. tested "hot" have a strength of approx. 0.8 MPa when hardened for $30 \mathrm{~s}$ and approx. $1.87 \mathrm{MPa}$ when hardened for $120 \mathrm{~s}$.
Moulding sands with a content of 1.0 p.p.w. tested in the "cold" state have a strength of approx. 2.0 MPa, regardless of the hardening time. Moulding sands with a content of 1.5 p.p.w. tested in the "cold" state have a strength of approx. 2.7 $\mathrm{MPa}$, and here no influence of hardening time on the strength of the moulding sands was observed. Moulding sands with a content of 2.0 p.p.w. tested in the "cold" state are characterized by a strength of approx. 3.3 MPa and there was no effect of hardening time on the strength of the moulding sands.

In the case of the Sibelco Poland sand matrix used to prepare moulding sands with hydrated sodium silicate, the obtained test results for the two types of binder, R145 and R150, were different. The moulding sands containing the R150 binder are characterized by strength properties similar to those of the moulding sands based on Grudzen Las sand matrix. In the case of composition with R145 binder, their strength in the entire tested range is lower by an average of $30 \%$. Strength values similar to other compositions are obtained by the moulding sand based on Sibelco Poland matrix with R145 binder, tested in cold state, with binder content of 1.5 and 2.0 p.p.w. hardened in 60, 90 and $120 \mathrm{~s}$. In the case of all tested moulding sands, curing for 30 seconds are characterized by the lowest strength properties in the hot state.

\section{CONCLUSIONS}

The analysis of literature data and our own research allow for the formulation of the following conclusions:

- The use of moulding sands with hydrated sodium silicate as a binder for ablation casting moulds is fully justified.

- From the ablation casting point of view, the most suitable sands with hydrated sodium silicate are physically hardened sands, which include thermal curing (warm-box) by dehydration.

- The results of tests obtained for Grudzen Las sand matrix to prepare moulding sands with hydrated sodium silicate with two types of binder, R145 and R150, are similar.

- The results of tests obtained for Sibelco Poland sand matrix to prepare moulding sands with hydrated sodium silicate with two types of binder, R145 and R150, are different. The results of tests obtained for the Sibelco Poland sand matrix to prepare moulding sands with hydrated sodium silicate with two types of binder, R145 and R150, are similar and are characterized by strength properties similar to those of the moulding sands based on the Grudzen Las sand matrix. In the case of compositions with R145 binder, their strength properties in the entire tested range are lower by an average of $30 \%$.

- The best strength properties are obtained by moulding sands containing 2 p.p.w. of binders examined in a "cold" state in the case of both tested sand matrixes.

- The research presented in this paper is a part of a wider ranging study which will be continued both in the context of the selection of moulding sands and the evaluation of the properties of the castings obtained by means of ablation casting technology. 


\section{Acknowledgement}

The research was financed by AGH Research Project No. 16.16.170.654.

\section{REFERENCES}

[1] Derui T. \& Haiping L. (2011). The ancient Chinese casting techniques. 69 $9^{\text {th }}$ WFC Paper 2010. China Foundry, 8(1), 127-136.

[2] Han Q. (2021). Ablation casting: solidification characteristics, microstructure formation, and mechanical properties. International Journal of Metalcasting. Doi: https://doi.org/10.1007/ s40962-020-00544-w.

[3] Grassi J.R. \& Campbell J. (2006). Solidification microstructure of aggregatemolded shaped castings, patent US 2008/0041499 A1, United States Patent Application Publication.

[4] Weiss D., Grassi J., Schultz B. \& Rohatgi P. (2011). Ablation of Hybrid Metal Matrix Composite, Transactions of the American Foundry Society, 119, 35-41.

[5] Grassi J., Campbell J., Hartlieb M. \& Major F. (2009). The Ablation Casting Process. Materials Science Forum, 618-619, 591-594.

[6] Weiss D., Schultz B. \& Rohatgi P. (2012). Discovering Ablation: An emerging technology known as ablation can achieve fine microstructure and better mechanical properties in casting alloys. Metal Casting Design \& Purchasing, January/February, 36-39.

[7] Weiss D., Grassi J., Schultz B. \& Rohatgi P. (2011). Testing the Limits of Ablation. Modern Casting, December, 26-29.

[8] Dudek P., Fajkiel A., Reguła T. \& Bochenek J. (2014). Badania nad technologią odlewania ablacyjnego stopów aluminium [Research on ablation casting technology for aluminium alloys]. Prace Instytutu Odlewnictwa, 54(2), 23-35.

[9] Grassi J., Campbell J., Hartlieb M. \& Major F. (2008). Ablation Casting. In: Yin W. \& Das S.K., Aluminium Alloys: Fabrication, Characterization and Applications. The Minerals, Metals \& Materials Society, Warrendale, 73-77.

[10] Bohlooli V., Shabani-Mahalli M. \& Boutorabi S.M.A. (2013). Effect of Ablation Casting on Microstructure and Casting Properties of A356 Aluminium Casting Alloy. Acta Metallurgica Sinica (English Letters), 26(1), 85-91. Doi: https://doi.org/10.1007/ s40195-012-0092-6.
[11] Taghipouriana M., Mohammadaliha M., Boutorabi S.M. \& Mirdamadi S.H. (2016). The effect of waterjet beginning time on the microstructure and mechanical properties of A356 aluminum alloy during the ablation casting process. Journal of $\mathrm{Ma}$ terials Processing Technology, 238, 89-95.

[12] Williams T.J., Galles D. \& Beckermann Ch. (2013). Translating Water Spray Cooling of a Steel Bar Sand Casting. In: Proceedings of the $67^{\text {th }}$ SFSA Technical and Operating Conference. Paper No. 5.4. Steel Founders' Society of America, Chicago.

[13] Izdebska-Szanda I., Angrecki M. \& Palma A. (2015). Dobór technologii formy dla zmodyfikowanej metody ablacyjnego odlewania [Choice of mould-making technology for the modified ablation casting process]. Prace Instytutu Odlewnictwa, 55(2), 55-66.

[14] Major-Gabryś K. (2016). Odlewnicze masy formierskie i rdzeniowe przyjazne dla środowiska. Gliwice: Wydawnictwo Archives of Foundry Engineering, Komisja Odlewnictwa PAN Katowice.

[15] Kamińska J., Hosadyna-Kondracka M., Puzio S. \& Major-Gabryś K. (2020). Jednorazowa forma odlewnicza, opis zgłoszeniowy wynalazku, PL 429888 A1. Biuletyn Urzędu Patentowego, 24, 16. Available on http://patenty.bg.agh.edu.pl/pelneteksty/PL429888A1.pdf.

[16] Hosadyna-Kondracka M., Major-Gabryś K., Kamińska J., Grabarczyk A. \& Angrecki M. (2018). Moulding Sand with Inorganic Cordis Binder for Ablation Casting. Archives of Foundry Engineering, 18(4), 110-115.

[17] Major-Gabryś K., Hosadyna-Kondracka M., Puzio S., Kamińska J., Angrecki M. (2020). The influence of the modified ablation casting on casts properties produced in microwave hardened moulds with hydrated sodium silicate binder. Archives of Metallurgy and Materials, 65(1), 497-502.

[18] Baliński A. (2000). Wybrane zagadnienia technologii mas formierskich ze spoiwami nieorganicznymi. Struktura uwodnionego krzemianu sodu i jej wpływ na wiqzanie mas formierskich. Wydawnictwo Instytutu Odlewnictwa, Kraków.

[19] CIATF - Comission 1.6, Alkali - Silica - Binder, 1982-1985, Düsseldorf, Germany.

[20] Różycka D., Stechman M., Wilkosz B. \& Baliński A. (2000). Szkło wodne jako spoiwo w odlewnictwie. Cz. II. Struktura. Chemik, 53(8), 215-219.

[21] Z.Ch. Rudniki S.A. (2016). Offer specification of the product: No. $14 / 7$.

[22] Z.Ch. Rudniki S.A. (2017). Offer specification of the products: Sodium silicate R150.

[23] Bryłka A. (2019). Dobór mas formierskich na formy do ablacyjnego odlewania stopów Al. AGH, Kraków [Master thesis]. 